\title{
Contributions of Nepalese Mathematicians during Shah and Rana Era
}

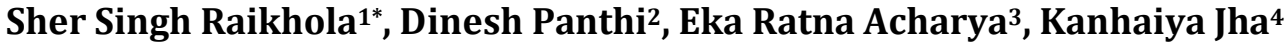 \\ ${ }^{1}$ Department of Mathematics, Bhaktapur Multiple Campus, Tribhuvan University, Nepal \\ ${ }^{2}$ Department of Mathematics, Valmeeki Campus, Nepal Sanskrit University, Kathmandu, Nepal \\ ${ }^{3}$ Central Department of Mathematics Education, Tribhuvan University, Kirtipur, Nepal \\ ${ }^{4}$ School of Science, Kathmandu University, Dhulikhel, Nepal \\ Email: *panthid06@gmail.com, raikholasher@gmail.com
}

How to cite this paper: Raikhola, S. S., Panthi, D., Acharya, E. R., \& Jha, K. (2020). Contributions of Nepalese Mathematicians during Shah and Rana Era. Advances in Historical Studies, 9, 130-141. https://doi.org/10.4236/ahs.2020.93012

Received: July 20, 2020

Accepted: September 21, 2020

Published: September 24, 2020

Copyright ( 2020 by author(s) and Scientific Research Publishing Inc. This work is licensed under the Creative Commons Attribution International License (CC BY 4.0).

http://creativecommons.org/licenses/by/4.0/

\begin{abstract}
The use of Mathematics, in human lives, can be found in different ways. There is a great impact of Mathematical contribution, the history and the study of Mathematics. That is to say, the study and analysis of Mathematical contribution provides endurance for Mathematics. Basically from the Lichchhavi period there begins the historical evidence of mathematicians in the nation. In the article, we explore and discuss mathematical contributions of Nepalese mathematicians and analyze content of different mathematics books written in the Shah and Rana Era (1742-1951).
\end{abstract}

\section{Keywords}

History of Mathematics, Contributions, Shah Era, Rana Era, Gurukula

\section{Introduction}

History of mathematics is a powerful tool for disseminating an understanding of mathematics. The history of mathematics reflects some of the noblest thoughts of countless generations (Jha, Adhikari, \& Pant, 2006). Mathematics originated from Vedic literature nearly 4000 years ago. Nepalese mathematical system is highly influenced by the world's mathematical system. Different contents on mathematics were authored by Indian mathematicians. They included the concept of zero, algebra and algorithm, square root and cube root (Acharya \& Pant, 2012).

Mathematics is one of the most important subjects, so it's importance and its position is in the top of the all researchers like the crest of the peacock, and the gem on the head of a snake. In Sanskrit as lagadha in his treatise Vedangajyotisha. 
It can be expressed as,

Yatha Sikha Mayuranaam, Naganam ManayoYatha|

Tatvad Vedanga Shastranam, Ganitham Murdhni Sansthitam \|

Vedangajyotisa -5 (Vedanga Jyotish of Lagadha)

Mathematics is a high level of abstraction gained by human mind. The Indus Valley civilization whose discovery was made in the nineteenth century exposed a long forgotten ancient culture. This culture contributed a lot to the development of Hindu traditions (Shrestha, 2013). Philosophy of Mathematics mentions that although the almost 3000 years old Vedas are mostly devoted to describing Gods and Goddesses, it represents ancient civilization as well as shows the origin of mathematics in such areas such as economic policy, algebra, geometry, astronomy and so on (Acharya, 2015). Sulva Sutra was developed in order to systematize geometrical knowledge that was developed from Hindu practices needed in making bedi and fire places (agnisthal) (Boyer, 1968).

Babylonian Mathematics includes different topics like fractions, algebra, quadratic and cubic equations, and the calculations of regular reciprocal pairs. The book also contains many useful tables; Pythagorean Theorem is also included in the book (Moffatt, 1977).

\section{Nepali Mathematics Books before the 1930}

Mathematics books entirely written in Nepali were started only after the beginning of the $20^{\text {th }}$ century. Some known mathematics books include Ankendushekhara (1900) written by Pahalman Singh Swar (1943). Ganitha Chandrika Part I and II by Gangadhara Shastri Dravid (1910), Ganita Prashna Sangraha by Raghunatha Pant (1914), Ganaka Sundari by Padmanath Pant (1916), Vichitra Ganita (part II) by Brahma Lal Shrestha (1918), Ganit Sagar (part I) by Ganga Prasad Shrestha (second ed.) (1921), Ganita Chandra Chandrika (part II) by Raghunatha Pant (1922), Sarala Bija Ganitaby Merunath and Kabiraj (1924), Gorakha Bija Ganita (part I - IV) by Nuru Datta Pande (-1925), Gorkha Table Book by Ramji Prasad (1931), Shishubodha Tarangini I (1931), and Shishubodha Tarangini II by Tikaram Dhananjaya (1933), Ankaganita by SD Vasu and KD Pradhan (1933), Mukhagra Ganita by Siddha Raj Joshi (1935 AD), and Hall and Steven's School Geometry translation by Narendramani (1935), Nepali commentary of Lilavati by Tikaram Dhananjaya (1936), and Nepali Saral Ganita (part I) by Parasmani Pradhan (1938) (Basyal, 2015).

The following mathematicians have contributions to Mathematics during the Shah and Rana era (1742-1951). Laxmipati Pande, Lila Nath Pande, Gopal Pande, Nuru Dutta Pande, Brahma Lal Shrestha, Tika Ram (Marasini) Dhananjaya, Chandra Kala Devi Dhananjaya, Tirth Prasad Pradhan, Narendra Mani Acharya, Prithavi Bahadur Singh, Pahal Man Singh Swar, Naya Raj Pant, Keshab Dev Bhattarai and Govind Dev Pant (Acharya \& Pant, 2012).

Prof. Ram Man Shrestha (2008), has announced the necessity of mathematics education in the 21st century New Nepal. He explained that the many myths, legends, and stories were told about the creation and origin of man with prehis- 
toric mathematics developments. Such evidence was found in Nepal. He enforced in the sense of encouragement to the revision and internationalizes the Nepalese's contributions in mathematics. It is followed by new generations and the study handled first in Nepal Sanskrit University from the dissertation with expressing the term Ganita Shastra (Acharya, 2015).

\section{Contributions of Nepalese Mathematicians during the Shah and Rana Era}

Historical development of mathematics is a highly interesting and exciting subject to research. It promotes our interest in mathematics and focuses the contribution of Nepalese people to the development of mathematics, which is used in every step of our daily life. Every research has its own specific objectives; this study has the following objectives. Historical descriptive method was applied to study the contents of the selected books. In addition, the researcher analyzed the documents as the contents analysis in the mathematical pattern. A different source expressed by Acharya (2015), the Shah and Rana era was 1742-1951.

Laureate Laxmi Pati Pande (1758-1831) was a famous astrologer and mathematician who advised King Prithvi Narayan Shah \& Bahadur Shah (1757-1797). He wrote the tikas of Bhaswati. He did mathematics and Jyotish study. He is regarded as the first Nepali astrologer. His book Bhaswati was the initial textbook of mathematics in Nepal (Pant, 2008). He also prepared planet star calendar. $\mathrm{He}$ is also known to be a great theologian in Nepal. He was honored as a royal astrologer.

Through remaining very busy in government jobs, Laxmi Pati Pande could find time to write texts in Astronomy in Sanskrit. Among his books, the celebrated one is "Ratna Deep" which contains theorems on Astronomy and Astrology. By the help of this book, the astrologer knows how to calculate exactly the eclipse period of Moon and Sun. Beside the prediction of eclipses, one can also determine the latitude and longitude of planes. Also he has shown in his book how to calculate exactly the Lagna, Muhurt and other times which are necessary to calculate the "panchanga"-the "Almanac". Pandit Laxmi Pati was a practical astronomer. He has constructed his own institution, the Sun-dial and other astronomical instruments (Acharya, 2015; Acharya \& Pant, 2012; Pant, 2008).

Besides the Ratna Deep, he is the author of following texts; Lilavati koTika, Bhaswatiko Tika, Kalarnaba Dipika, Bhaskariya Bija Ganita, Muhurt Chintamani, Budhibitasini, Laghu Parashari Tika, Jannadhanakal Nirupan, Bhuwandeepak Tika, Jatakalaknara, Grahanayana Saranac, Jatak Sudhar, Brihatparashar Sahitko Bhukmpadhyaya Matika and Griha Laghava Kalarnav Dipika (Pant, 2007; Pant, 2008).

On the other hand, he had written nearly one and half dozen books and he had constructed some scientific instruments like Sundial.

1) The sundial (to determine the time in a day time). 
2) A balance type Levellor (to find the level and to find the angle of elevation and angle of depression).

3) A chart to draw the increasing and decreasing phase of the Moon.

4) A chart to show both the sun and the moon eclipses (Pant, 2007; Pant, 2008).

Lila Nath Pande (1786-1832) was the son of Laxmi Pati Pande and he was born on September 131786. He was also a Royal astrologer and great scholar of Mathematics. He also wrote a book in Nepali known as Siddhanta Jyotish but it had not been published (Tewari, 1973).

The first mathematician Pandit Gopal Pande (1847-1920) wrote mathematics books in Nepali language. He had written the first Mathematics book Wyokta Chandrika in 1883 (Pande, 1883). This book was based on Bhaskaracharya (II). He made a great contribution in mathematical development. Many students got plenty of benefits from his book. The book was equally useful to calculate square and cube root.

The first book of mathematics is Wyokta Chandrika contains numerous problems dealing with favorite topics of Hindu mathematics: linear and quadratic equation, geometric progression, surds, Pythagorean triads, determinants and indeterminate, simple mensuration, arithmetic and geometric progressions and others (Dhananjaya, 1933).

Gopal Pande had expressed the rule of three in square root and cube root. It is similar to Bhaskaracarya's expression. Bhaskaracarya said, "In the entire mathematics rule the rule of three is used except square root and cube roots" (Acharya, 2011). This is expressed in Sanskrit verses can be expressed as,

Varga Vargapadam Ghana Ghanapadam Satyajya Yat Ganyate

Tat Trairashikmewa Bhedabahulam Nanyattato Vidhyate (Pande, 1883).

The first calendar published in 1884 in Nepal claimed that there was lunar eclipse of Aswin sulka. But Gopal Pande proved it to be wrong with his astrologic calculation. Then he was honored with Royal Astrologer. He is the first writer of Mathematics book of Nepal, a great mathematician and scholar of other subjects too. His next popular book is "Lokanusmiriti". It explains about Loktantra. Trizoidiacle rule (Pant, 1980), was first to formulate by Pandit Gopal Pande.

He was a great scholar with deep knowledge of mathematics, astronomy, engineering, linguistics, and geography. These characters are reflected in his following contributions.

- Design of Tudikhel in Kathmandu, Nepal.

- Correction of eclipse in the calendar published in 1884.

- Publication of Lokanusmriti [in Hindi Language].

- Concept of rotation of the earth based on the concept given by Bapudeve Shastri [in Hindu Language].

- Development of astronomy and mathematics.

- Teaching at Sanskrit Pathasala in Kathmandu (Acharya, 2010).

By and large, his contribution in mathematics played a vital role in the development of mathematics educational history of Nepal. 
Other famous Scholar and writer in mathematics Nuru Dutta Pande (19th Century) was second son of GopalPande. He had written a Mathematics book named Gorkha Bija Ganita Shiksha (1 - 4 part) (Acharya, 2009; Pande, 1925/26). This shows his great ability of algebra. Also he has composed the mathematics book so called Bichitra Ganita. His brother Master Meru Nath Pande and poet Raja Pande had written Saral Bija Ganita in Nepali language.

Brahma Lal Shrestha, the one of the Nepalese mathematicians of modern times, was born on December 22, 1889 at Marubicche Tole, Basantapur in Kathmandu. He was a sharp minded intellectual, could solve big calculations orally in childhood and kin interested since he was child. The remarkable contribution of Brahma Lal Shrestha in Nepalese mathematics is through his book named $V i$ chitra Ganita (Kadel, 2015; Shrestha, 1918; Acharya, 2018).

In this book, there are many mathematical problems related to Square and Square root, Fraction and Decimal, Cube and Cube root, HCF and LCM, Profit and Loss, Percentages, Ratio and Proportion, Unitary Method, Chain Rule, Simple interest and Compound interest, Area, Perimeter and Volume, Simultaneous equations, verbal problems, commission etc. One interesting thing in this book is it has 50 parts and each parts contains eight mathematical questions so there is total 400 mathematical questions written in Nepali in Vichitra Ganita which is very much similar to book named Ganita Sagar of Ganga Prasad Shrestha which was published two year before this and provided answer of each questions so that it look likes practice book which helps students achievements (Kadel, 2015).

Tika Ram Marasini (1909) was born in Arghakhanchi, Khidim and was a multi dimensional person. He was a poet, translator, commentator, writer, grammarian and advocate of science. Marasini published Ritumanjari in 1928. He was writing Sishubodha Tarangini (Acharya, 2015; Dhananjaya, 1934), (part 2, 3) in 1934. Nowadays part 1 and part 3 of Sishubodha Tarangini are not found. $\mathrm{He}$ published a commentary of Lilavati of Bhaskaracharya (second) in Nepali medium, similarly Bhaswati. Such creations and works were supported to him appointed as the headmaster of that school.

Tika Ram (Marasini) Dhananjay and Chandrakala Devi Dhanajaya had contributed for writing Shishubodh Tarangini par1 (1931), Sishubodha Tarangini part 2 (1934), Shishubodh Tarangini part $3(1933 / 1934)$ this is one of the very rare books for today. He had also written Laghu Kaumudi and other so many books on Mathematics and literature. The presentation is in prosody style written in Nepali Language; such as,

“Kohi Eka Rukhama Thiye Dui Bagal Suga Baseka Pani Tyaha Ekathar Bhandathe Timiharu Euta Pathayaubhane Hunchhau Dobbar, Bhandathe Aru Thari Eka Aaudamayaha Hunchhau Barabari Bhan Kati Suga Rahechhan Tyaha?" (Prasit, 2004).

Now, converting these prosody styles of mathematical equations into symbolic form, let $\mathrm{x}$ and $\mathrm{y}$ be the number of parrots in first and second group then as described in prosody we have,

$$
x+1=2(y-1) \text { or } x-2 y=-3
$$


and

$$
x-1=y+1 \text { or } x-y=2
$$

Solving (1) and (2) we get $x=7$ and $y=5$. Hence $7 \& 5$ are the number of parrots (Acharya \& Pant, 2012).

In this way Marasini has written so many books but some are given as,

Ritumanjari (1928), Sishubodha Tarangini (part 1-1931), Sishubodha Tarangini (part II-1934), Bhaswati (1933), Sishubodha Tarangini (part 1-1933-1934), Lilavati, Tika (commentary), Laghukaumudi, Upadesh Chandrakala, Yatra Manjari, Upadesh Manjari (1924). Shiksha Manjari, Niyamita Manjari, Shreedhar Nataka, Kamshastra, Sanskar Kalpalata, Ekyarnava Sharaddha (Adhikari, 2002).

About Eighty four years ago in 1833 one Nepali woman (Pant, 2004). Chandra Kala Devi Dhananjaya (1915-2002), has written and published Shishubodh Tarangini Ganita in Sloks form. Which is a remarkable contribution of Chandra Kala Devi Dhananjaya in development of mathematics in Nepal at that time. In this book, simple addition, multiplication, division has been explained in a simple way to understand. It includes two parts. She is supposed to be the first successful woman mathematician I Nepal. Her contribution is huge. She taught mathematics and assisted a lot to spread the rays of mathematics in Nepal. Shishubodha Tarangini is based on mathematics and astronomy. Some contents were cited from Aryabhatta, lilavati and Wyotka Chandrika (Prasit, 2002). It was published for teaching mathematics and Jyotish to children. It contained 80 pages in total. In this book, many mathematical problems are related to Fractions, HCF, LCM, Profit and Loss, Decimal, Unitary method, Square root and Cube root, Simple Interest, and Sequence etc. are given with suitable examples. The first verse of this book is an invocatory verse on Lord Ganesh, Kuldevta, and other gods (Adhikari, 2015). Firstly, she defines the various units of money, which were in vogue during those days.

Shishubodha Tarangini Ganita was written in three parts; First, Second and Third respectively but only the second part is available.

Masterpieces published by Chandra Kala Devi

- Upadesh Chandrakala (Part I)

Published date-1934 Publisher-Ba. Shiva Prasad Radhoram, Gorkha Pustakalaya, Ramaghat, Baranashi.

- Shishubodha Tarangini (Part I \& III) (Unavailable)

- Shishubodha Tarangini (Part II)

Published date-1934 Publisher-Ba. Shivaprasad Radhoram, Gorkha Pustakalaya, Ramaghat, Baranashi (Adhikari, 2015; Prasit, 2002).

Tirha Prasad Pradhan (1918-2010), was born in 1918 as a son of father Narayan Prasad Nhuchhe Pradhan and Mother Hiramaya Nhuchhe Pradhan at very core area Maturity Role of Kathmandu Valley (Acharya \& Pant, 2012). He has written Nepali Arithmetic, School Geometry, Algebra, Elementary Trigonometry, and Elementary Dynamics. Pradhan has written some English Prosody; 
collection of diving songs (translation). He was rewarded on so many occasions with regarding his teaching experiences in Mathematics and social contributions. As the honors of him he has received various medals and appreciated letters. Some are as: Janpadha Sewa Padak, Gold Medal, Golden Jubilee Year 2004, (Siddhartha Vanasthali Institute, Balaju), Gorkha Dakshina Bahu, Dirgha Sewa Padak, and His Majesty's King Birendra Shuvarajyavishek 1999 (Pradhan, 2000).

Some Mathematics books were translated into Nepali language in the nineteenth century. Among these, the Arithmetic book was the main book of Narendra Mani Acharya. It was a translation of arithmetic book of Yadav Chandra Chakravarti. Similarly, Nepal Bhasa Prakashini Samiti has published "Nepali Arithmetic" in 1834; the book has grammatically correct language. Words were translated into English from Nepali words correctly. Considering it as a standard book various high schools taught this book to their students (Jha, Adhikari, \& Pant, 2006).

Another remarkable writer Pahalman Singh Swar (1978-1934) was born at Ridikot, Achham of Seti zone. Swar was highly interested in mathematics since his early childhood. He is famous for his masterpiece, Ankendrashekhar. Actually, Swar is a literary figure of Nepal. Despite being a lover of literature, he wrote a book of mathematics which has its own special importance. But the book $A n$ kendrashekhar has become almost rare these days due to the lack of certain incentives needed for its preservation. The book found in a photocopy paper was reprinted and published in 1953. The book has its preface on the second page of the book. There is a description of Dedication on the fourth page and Pahalman Singh Swar at the end of the page (Acharya, 2015; Swar, 1943).

He had written Ankendushekhara which influenced Nepali mathematics (Swar, 1943). It contains the elementary concept of mathematics based on four fundamental operations of mathematic

Thus the book contains different figures and digits of mathematics. It also has the methods of multiplication. But the interesting thing about the book is that most of the rules of mathematics have been given in rhyming words which enable children to memorize fast and easily. Dinesh Raj Pant claims that the book Ankendrashekhar was printed third time from the Gorkha Pustakalaya, Ramghat, and Kashi. The book written for kids was very useful for the contemporary society (Acharya, 2015; Pant, 1992).

Raja Jaya Prithvi Bahadur Singh (1977-1940), is the eldest daughter son-in-law of Rana prime minister Chandra Smasher and grandson of Jung Bahadur from daughters line (Bhattrai, 1999). He had published several books of mathematics by 1913. Out of these books, the most renowned book is Aksharanka Shiksha" which was published in 1901. But the book remained unnoticed for several years (Acharya, 2015). The Mahabharata Jay Prithvi Anushandhanudhyan (Raphaj) brought the book into the mainstream of study (Acharya, 2015; Singh, 1901). The book is useful not only to use basic learners of mathematics, it's equally important to the adults in a sense that the book helps the adults to solve math's related daily household problems. The book has occupied its distinct role place in 
the vast world of mathematics. The book has all basic elements of mathematics like the digits from 1 to 100 , multiplication table from 1 to 20 , square roots of 1 to 100 and other tables. The book also has tens multiplication chart including tens, hundreds, thousands lakhs. He has substituted tens multiplicities words with Sanskrit words like Eka, Dash, Shata, Sahasa, Ayuta, Lakshya etc. The book which is written in Nepali language provides four basic rules of Math's i.e. addition, subtraction, division and multiplication. The book also contains various methods of measurement of land, weightage of goods and measuring time periods like year, months, days, dates, seasons, etc. (Acharya, 2015). The most famous book written by Jay Prithvi Bahadur Singh was Balbodh No. 1 in the same year. Another book called Balbodh No. 2 has the digits from 1 to 100 (Singh, 1901).

The person who has made such a great contribution in mathematics was not recognized well by the contemporary Rana rules. The Rana rules did not tolerate his liberal nature and devotion to education. That's why he left Nepal and went to the foreign countries in 1916. Mr. Singh occupied a superior place in the area of mathematics in Nepal through his two masterpieces, Aksharanka Shiksha and Balbodh No. 1.

The Rana Prime Minister Dev Shamsher wanted to establish around 300 schools across the nation and distribute the Aksharanka Shiksha book free of cost to hundreds of students. But his desire couldn't materialize fully due to conspiracy within his family. However, many schools were set up during his tenure and the book was distributed. The Aksharanka Shiksha is regarded as the first prescribed Maths book in Nepal (Singh, 1901).

Naya Raj Pant (1913-2002), was born on $10^{\text {th }}$ Aug 1913 at Mahaboudha, Kathmandu (Pant \& Acharya, 2011). He was recognized as a great Scholar of Mathematics in Asia. He was a self-learner and seen very much inquisitive in mathematics and Jyoatisha Ganita. He was praised as a great astronomer and mathematician by foreign scholars.

He was awarded many times for his pioneer works in the field of research and publications. Among them the Lichhavi Samvatko Niranaya, is the very remarkable work. He had established Samasodhana Mandala in 1953. With the help of his students and Published Itihasa Samsodhan, Samadhan-patra, Byakarana Samsodhan and Panchanga Samsodhan. The Samsodhan Mandala has published the famous Journal Purnima from 1964 and he has written dozens of essays on mathematics astronomy, records of Nepalese history, etc. Pant examined earlier studies of ancient mathematics especially in astronomy, jyotisha, cube root, trigonometry, Sumatitantra and analysis of manuscripts of mathematics (Acharya, 2012; Acharya \& Pant, 2012).

In an article entitled The relation of diameter to circumference in local language Nepali by professor Pant on Purnima-5 (Year 2, Number 1), professor Pant gives a new verse in Sanskrit to suggest the value of $\pi$ which can be expressed as:

Byasebhanandagnihate Bibhakte Khabanasuryeh Paridhihsasukshmah I Dawa- 
wimshatidhnebihtesthasgailaih Sthulosthawashyadabyawaharayogyah II (Pant, 1965).

(Circumference must be calculated by multiplying diameter by 355 and dividing the result by 113 . We can multiply diameter by 22 and divide by 7 which gives coarse result which can be taken for common use), that is, the value of $\pi=$ $355 / 113=3.1415929 \ldots$

The major contributions of Pant are listed as below.

- Simplified the way of presenting mathematical content.

- Critically analyzed previous mathematical works.

- Compared Hindu mathematics with Greek mathematics.

- Continuously studied Nepalese mathematics history (Acharya, 2015).

List of mathematics books written by pant are: Jyotisha, Sumatitantram, Golabodha, Pandit Gopal Pande ra Unako Ghanmula Lyaune Riti, Prachin Ganita ra Nabin Ganita ko Tulana, Trikonmiti Kalachakra ko Jyoatisha Bhag Ra Tyasha ko Vivechana $\left(1^{\text {st }}\right.$ part, $\left.2^{\text {nd }} \& 3^{\text {rd }}\right)$, Hindu Siddhanta Jyotish Ra Greek Sidhanta Jyotishko Tulana, Ratna Deep ( $1^{\text {st }}$ and $2^{\text {nd }}$ part) (Acharya, 2015).

Keshav Dev Bhattarai (1913-2007) was born in $13^{\text {th }}$ July 1913 (Pant, 2009). He received the Master's degree from Calcutta University in 1939. He was the second M.A. Degree holder in the whole of Nepal. At first he served as a volunteer in Durbar High School and Tri-Chandra as a Mathematics teacher. He had actively participated in more than a dozen seminars and workshops in Nepal and abroad. In 1961 he had gone to Bombay to attend a seminar in Topology. Besides being the life member of Nepal Mathematical Society. He was a member of the Indian Mathematical Society. On behalf of this pioneer contribution he was profusely honored and rewarded by the various academic institutions. He was rewarded with Gorkha Dakshin Bahu (Acharya \& Pant, 2012).

Govinda Dev Pant was born in the well-established Pant family at Kamal Pokhari Kathmandu on the 17th Jan 1923 (Pant, 2007). His grandfather Kumar Dev Pant was a high level civil servant and had received the well honored pundit of Sardar from the Rana Govt. of that time. He was appointed as a professor of mathematics in Tri-Chandra College in 1959. Pant wrote Integral Calculus which is a textbook in Bachelor Level.

\section{Conclusion}

Historical development of Mathematics is highly interesting and exciting subject to research. It promotes our interest in Mathematics and focuses the contribution of Nepalese Mathematicians during the Shah and Rana Era to the development of mathematics, which is used in every step of our daily life.

Laxmi pati Pande, the first Nepali astrologer was also known as Royal astrologer. He prepared planet-star calendar and redicted about the eclipses based on his Bhashwati, the initial book of mathematics. He had constructed some scientific instruments like: sundial, Balance typer Leveler and A chart to draw the increasing and decreasing phase of the moon, etc. Lila Nath Pande was also a Royal astrologer and great scholar of Mathematics. 
The first mathematician Pandita Gopal Pande (1847-1920) wrote mathematics books in Nepali language. He had written the first Mathematics book Wyokta Chandrika in 1883 (Pande, 1883). He utilized the Trizoidiacle Rule that is useful to calculate square and cube root, which is considered a remarkable contribution to Nepali mathematics. In the nineteen century Nuru Dutta pande had written first, second, third and fourth parts of Gorkha Bija Ganita (Acharya, 2009).

The contributions of Brahma Lal Shrestha in Nepalese mathematics through his book named "Vichitra Ganita". By means of publishing the book, he had played a great role in the development of mathematics (Acharya, 2015; Kadel, 2015).

Tikaram Dhananjaya had contributed in Nepali mathematics through Shishubodha Tarangini with his wife Chandrakala Devi Dhananjaya in 1933. He had also written Laghukaumudi and other so many books on mathematics and literature. He had contributions in Veda, jyotisha, Ayurveda, Panchang, etc. In Nepal Chandrakala Devi Dhananjaya, was the first woman mathematicians (Acharya, 2015). She had written shishubodha Tarangini part one and part two.

Tirtha Prasad Pradhan has written Nepali Arithmetic; School Geometry, Algebra, Elementary Trigonometry, and Elementary Dynamics. He was very eager for the development of mathematics and worried to Nepalese history of mathematics.

Naya Raj Pant was an eminent historian, astrologer, and mathematician and Sanskrit scholar of Nepal. He was awarded many times for his pioneer works in the field of research and publications. Among them the Lichhavi Samvatko Niranaya, is the very remarkable work. He established Samshodhana Mandala in 1952 (Pant \& Acharya, 2011).

Finally, In Nepalese Mathematical development in Nepal like: LaxmipatiPande, Lila Nath Pande, Gopal Pande, Nuru Datta Pande, Brahma Lal Shrestha, Tikaram Dhananjaya, Chandrakala Devi Dhananjaya, Narendra Mani Acharya and Naya Raj Pant, etc., had provided Valuable Contributions in mathematics during the Shah and Rana era.

\section{Acknowledgements}

We like to express the sincere thanks to ancestors of mathematics specially Professors Naya Raj Pant, Ram Man Shrestha, Shankar Raj Pant, Dinesh Raj Pant and Mahesh Raj Pant, Indra Natha Aryal that encouraged the history of mathematics directly and indirectly. This paper is dedicated to the South Asian Sub Continental mathematicians.

\section{Conflicts of Interest}

The authors declare no conflicts of interest regarding the publication of this paper.

\section{References}

Acharya, E. R. (2009). Gorkha Bija Ganita Shikshako Samikksha. Mathematics Education Forum, 8-15. 
Acharya, E. R. (2010). Role of Gopal Pande in History of Mathematics in Nepal. Mathematics Education Forum, Council for Mathematics Education, Kathmandu, No. 27, 21-26.

Acharya, E. R. (2011). A Research Report: An Analytical Study of Nepalese History of Mathematics. Kathmandu, Nepal: Research Division, Tribhuvan University.

Acharya, E. R. (2012). Prof. Naya Raj Pant as an Institution of Mathematics. Journal of Ramanujan Society of Mathematics and Mathematical Science, 1, 23-28.

Acharya, E. R. (2015). Naya Raj Pantaka Ganitiya Kritiharuko Adhyayana. Unpublished PhD Thesis, Dang, Nepal: Nepal Sanskrit University.

Acharya, E. R. (June 2018). Historical Information of Mathematics in Nepal, Research Based Information. Champa Acharya, Butwal, 15, Rupandehi.

Acharya, E. R., \& Pant, S. R. (2012). Glimpse of Nepalese Mathematicians. Proceedings of National Conference on Mathematics (NICS 2012), 20-22 January 2012.

Adhikari, A. R. (2002). Unnayan. Publication, Kathmandu.

Adhikari, B. (2015). Mathematical Contribution of First Nepali Women Mathematician Chandrakala Devi Dhananjaya. Unpublished Thesis, Kathmandu, Nepal: Tribhuvan University.

Basyal, D. (2015). A 1933 Nepali Mathematics and Astrology Book Sishubodha Tarangini, Translation and Commentary on Mathematics Chapters. Unpublished PhD. Desecration, Las Cruces, NM: New Mexico State University.

Bhattrai, S. S. (1999). “Jay prithavi Bahadur Singhka Dui Rachana”, Khoji Ani Byakhya. Nepal Rajakiya Pragyapratisthan, 203.

Boyer, C. B. (1968). A History of Mathematics. New York: John Wiley \& Sons. Inc.

Dhananjaya, C. D. (1933). Shishubodha Tarangini (Part II). Ramghat, Varanasi: Ba. Shiva Prasad Radhoram, Gorkha Pustakalaya.

Dhananjaya, C. D. (1934). Shishubodha Tarangini-2. Gorkha Pustakalaya, Ramghat, Banaras City.

Jha, K., Adhikari, P. R., \& Pant, S. R. (2006). A History of Mathematical Sciences in Nepal. Kathmandu University Journal of Science, Engineering and Technology (KUSET), 2, 1-6.

Kadel, K. P. (2015). Biography of Brahma Lal Shrestha and His Contribution on Nepalese Mathematics. Unpublished Thesis, Kathmandu, Nepal: Tribhuvan University.

Moffatt, M. (1977). The Ages of Mathematics. Gardner City, NY: Doubleday.

Pande, G. (1883). Wyokta Chandrika. Mumbai: NirnayaSagar Press.

Pande, N. D. (1925/26). Gorakha Beej Ganita Shiksha 1-4 Part. Government of Nepal/Mir Subba Rammani Acharya/Gorakha Bhasha Prakashani Samiti.

Pant S. R. (2007). Short Biography of Gobind Dev Pant. Nepal Mathematical Society, Newsletter, No. 3, 7-8.

Pant, D. R. (1992). Buddhadekhi Pahalmanasamma (p. 111). Kathmandu: Shajha Prakashan.

Pant, N. R. (1965). Relation of Diameter to Circumference (Vyas ra Paridhiko Sambandha). Purnima, 2, 75-89.

Pant, N. R. (1980). Pandit Gopal Pande and His Method of Getting Cube Root. Kathmandu: Royal Nepal Academy.

Pant, N. R., \& Acharya, E. R. (2011). Tika Ram Dhananjaya in Mathematics Science. Mathematics Education Forum, Council for Mathematics Education, Kathmandu, No. 29, 44-49.

Pant, S. R. (2004). Mathematics in Nepal, as a Historical Analysis. Scientific World, 3, Ministry of Environment, Science and Technology, Kathmandu. 
Pant, S. R. (2008). Astrologer Pandit Laxmipati Pande. Newsletter, Nepal Mathematical Society, No. 4, 13-14.

Pant, S. R. (2009). Prof. Keshav Dev Bhattarai. Newsletter, Nepal Mathematical Society, No. 5, 11-12.

Pradhan, T. P. (2000). Short an Autobiography (Tritha Prasad Pradhan). Taleju-Dhana Kumari Kosha.

Prasit M. N. (2002). Bahumukhi Pratibha Tikaram Dhananjaya. Anamnagar, Kathmandu: Unnayan Prakashan.

Prasit M. N. (2004). Bahumukhi Pratibha Tikaram Dhananjaya. Pasina Publication, Lumbini.

Shrestha, B. L. (1918). Vichitra Ganita. Kathmandu: Pasupati Press.

Shrestha, M. B. (2013). Philosophy of Mathematics. Kamaladi, Kathmandu: Nepal Pragya Pratisthan.

Shrestha, R. M. (2008). Mathematics Education for the Twenty First Century New Nepal (p. 29). Kathmandu: Nepal Academy of Science and Technology.

Singh, J. B. (1901), Aksharanka Shiksha. Kathmandu: Pasupat Press. (Punhaprakasit 2000)

Swar, P. M. S. (1943). Ankendrushekhar (2nd ed., p. 4). Banaras: Sarwahitaisi Ltd., Jalpa Devi Road, Banaras.

Tewari, R. (1973). Raj Jyotishi Lilanatha Pande le Nepali Bhasama Lekheko Siddhant Jyotish. Purnima, Anka, 29: Sansodhan Mandal, 7. 